\title{
Níveis Significantes do Significado das Estações do Ano com o Uso de Diversidade Representacional na Formação Inicial de Professores de Ciências
}

\section{Significant Levels of the Meaning of Seasons with the Use of Representational Diversity in the Initial Science Teacher's Formation}

\section{Daniel Trevisan Sanzovo ${ }^{\circledR}$ Brasil Carlos Eduardo Laburú ${ }^{\circledR}$ Brasil}

O objetivo deste estudo é verificar e compreender o nível significante atingido por alunos de licenciatura de ciências biológicas de uma universidade estadual através da utilização de uma Diversidade Representacional sobre as Estações do Ano. Utilizou-se um instrumento analítico baseado numa particular reformulação do conceito peirceano de interpretantes que permite ao professor qualificar o alcance da formação do significado construído pelos estudantes. Constata-se que os estudantes atingiram profundos níveis significantes de significados acerca do conteúdo estudado. Foi possível também identificar a eficácia do instrumento analítico como ferramenta a ser utilizada em sala de aula, como auxílio no acompanhamento, pelo professor, da produção e desenvolvimento dos significados adquiridos pelos estudantes, bem como ser possível utilizá-lo também como apoio pedagógico na preparação de aulas e escolhas de materiais didáticos.

Palavras-chave: Aprendizagem científica; Níveis Significantes Peirceanos; Diversidade Representacional; Astronomia.

The aim of this study is to assess and understand the significant level reached by undergraduate students of biological sciences of a state university by the use of a Representational Diversity on the seasons. We used an analytical tool based on a particular reformulation of the peircean concept of interpretant which allows the teacher to qualify the scope of the formation of meaning built by students. It appears that the students reached deep significants levels of meaning about the study content. It was determined the effectiveness of the analytical instrument as a tool to be used in the classroom as an aid in monitoring by the teacher, the production and development of meanings acquired by students as well as be able to use it also as teaching aids in the preparation classes and materials choices.

Keywords: Science Learning; Peircean Significant Levels; Representational Diversity; Astronomy. 


\section{Introdução}

A pressa do dia a dia, aliada ao avanço tecnológico e científico das últimas décadas, contribui com uma maior visão e entendimento do Universo em que vivemos ao passo em que os equipamentos astronômicos melhoram suas resoluções a cada instante. Simultaneamente, o homem tem deixado de apreciar os fenômenos da natureza devida, em parte, a essa correria cotidiana, fazendo com que as ciências naturais estejam cada vez menos naturais (Horvath, 2013).

Por sua vez, a educação científica preconiza como um de seus principais objetivos a efetiva aprendizagem dos significados, em oposição a uma aprendizagem mecanicista e com base na memorização de alguns dados, para que o aprendiz construa não somente conteúdos conceituais, mas também procedimentos e valores a respeitar envolvidos com tais conteúdos (Zabala, 1998). Entretanto, a construção dos conceitos permanecerá superficial e pouco consciente se a aprendizagem se der sem significado, não havendo modificação de valores, atitudes e comportamentos desejados, enquanto que procedimentos e atuações sobre o mundo tornam-se irrefletidos, conservando-se dissociados e sem um mínimo de articulação entre si. O estudante, nesse caso, ao utilizar o conhecimento científico, o faz tão somente para dar cumprimento às circunstâncias escolares, sem chegar a entender o que realmente está dizendo e/ou realizando e, portanto, sua compreensão se manifesta basicamente de maneira mecanicista, com memorização de curto prazo, repetitiva ou imitativa.

Pesquisas procuram entender o mecanismo e a estrutura cognitiva através dos quais os aprendizes acessam o conhecimento e constroem significados para promover a integração entre as interpretações dos fenômenos e as explicações científicas. Neste contexto, revela-se a importante questão do que seja significado para qualquer educador e pesquisador preocupado com processos de ensino e aprendizagem. Vygotsky afirma, por exemplo, em sua obra Pensamento e Linguagem (2003), que o significado, por ser um fenômeno de pensamento, deveria ultrapassar uma simples resposta para sua compreensão. A complexidade do termo é ressaltada em processos de comunicação: o falante abstrai o estado de consciência, utiliza-se de signos, intencionais ou não, para se comunicar e, este comportamento é percebido pelo indivíduo a que se destina a comunicação, que dela abstrai os elementos funcionais, reconhecendo-se sua significação, procurando concretizar esta última reconstituindo um estado seu de consciência semelhante ao do primeiro indivíduo (Buyssens, 1967). Sua importância também é percebida em situações educacionais, quando nos damos conta que as experiências diretas de cada estudante em relação ao mesmo objeto normalmente diferem, ainda que possam ter em comum o mesmo significado. Ou ainda, quando aprendizes conseguem perceber claramente o que o professor quer dizer com um signo particular, assim como sabem distinguir em que grau dois significados são idênticos ou diferentes.

Historicamente, seguindo as repetidas demonstrações de Piaget de que as crianças pensam sobre o mundo de maneiras muito diferentes do que os adultos, os pesquisadores educacionais no final da década de 70 do século passado começaram a ouvir atentamente 
o que os estudantes diziam e faziam em uma variedade de tarefas relativas aos diversos conteúdos científicos aprendidos na escola. Chegaram à conclusão de que estes aprendizes tinham ideias que competiam, muitas vezes de forma bastante eficaz, com os conceitos científicos apresentados em sala de aula. Em outras palavras, os alunos não iam para as suas respectivas salas de aulas como tábulas rasas e sim haviam desenvolvido concepções duráveis com poder explicativo, sendo estas, muitas vezes, inconsistentes com os conceitos matemáticos e científicos aceitos apresentados na instrução (Smith, DiSessa, \& Roschelle, 1993). Inicia-se assim um dos marcos da educação científica, denominado de movimento das concepções alternativas (Cachapuz, De Carvalho, Praia, \& Vilches, 2011), uma das principais linhas de investigação da didática das ciências, em que pesquisadores começaram a se preocupar com os conteúdos das ideias dos alunos sobre os conceitos científicos. Com relação à Educação em Astronomia, a pesquisa sobre concepções alternativas de conceitos astronômicos já está bem consolidada (Lelliott, \& Rollnick, 2010). Entretanto, professores de ciências raramente tiveram conteúdos de Astronomia em sua formação (inicial ou continuada), fato devido, essencialmente, a uma defasada formação docente, implicando no desconhecimento (ou uma não tomada de consciência) das concepções alternativas usadas por eles, e por seus alunos, muitas vezes incorretas, para explicar os fenômenos astronômicos (Langhi, 2004; Leite, 2002; Lima, 2006; Puzzo, 2005;). Outra importante ponderação é que esse ramo do saber, assim como a Física, apresenta-se para muitos como uma ciência abstrata, que requer grande reflexão e interpretação para ser compreendida (Batista, 2004), gerando uma falta de conhecimento científico sobre o tema (Carvalho, \& Gil Pérez, 2001).

Para a aprendizagem das ciências, no caso específico, aprendizagem de conceitos astronômicos, uma questão capital para o professor é a possibilidade de acompanhamento da produção e desenvolvimento dos significados que os estudantes vão adquirindo durante o processo de ensino, com o objetivo de direcioná-los e enquadrá-los ao conhecimento científico. No presente estudo, diferentemente do que ocorre com a corrente da mudança conceitual, por exemplo, que constrói seus fundamentos na filosofia da ciência (Posner, Strike, Hewson, \& Gertzog, 1982) e na psicologia cognitiva (Osborne, \& Wittrock, 1983), e cuja preocupação fundamental é a alteração das concepções dos alunos num marco cognitivo desprovido de interesses semiológicos (Laburú, \& Silva, 2011a), procura-se fundamentar a questão do significado no plano da semiótica peirceana. Com o objetivo de aprimorar e testar a eficácia de um instrumento analítico que auxilie o professor na árdua tarefa de qualificar o significado apropriado pelos estudantes, procura-se responder a questão de pesquisa de quais níveis de significado, embasado numa leitura dos níveis significantes de Peirce, os estudantes de graduação de Ciências Biológicas apresentam após a utilização da estratégia de ensino que usa a Diversidade Representacional acerca das Estações do Ano. Nessa perspectiva, a representação de um conceito passa, portanto, a ser concebida como sendo uma interação de um signo, interpretante e referente, engendrando essencial mudança da atenção do significado como sendo decodificado a partir de uma representação para uma visão de que o significado 
é feita com a representação através de um processo de semiose, isto é, de interpretação (Tang, \& Moje, 2010). Como será visto em seção posterior, essa perspectiva implica que a aprendizagem científica é atrelada ao trabalho representacional do conceito em questão, e a utilização de uma Diversidade Representacional possui papel fundamental.

\section{Significados de Significado}

O termo significado, em teoria da linguagem, é um dos mais ambíguos e controversos, tornando-se inutilizável para termos científicos (Ullmann, 1964). Ogden e Richards (1989), em The Meaning of Meaning, trabalho seminal publicado originalmente em 1923, afirmam que as expressões dos filósofos não são confiáveis quando fazem menção ao referido termo, tendo recolhido dezesseis significações diferentes. Na referida obra, os autores listam três grupos distintos de um total de dezesseis definições do termo. $\mathrm{O}$ primeiro deles compreende fantasmas gerados linguisticamente, o segundo agrupa $\mathrm{e}$ distingue usos ocasionais e erráticos, enquanto que o terceiro "abrange situações gerais de Signo e Símbolo" (Ogden, \& Richards, 1989, p. 248, tradução nossa). Desde então, diferentes outros termos foram acrescentados a esta "formidável fonte de ambiguidade" (Ullmann, 1964, p. 111).

A raiz de problemas das confusões verbais, isto é, do problema do que seja significado, deriva da superstição de que as palavras são de alguma maneira parte das coisas ou sempre implicam coisas que lhes correspondam (Ogden, \& Richards, 1989). Entretanto, por ser um tipo particular de signo, a palavra não necessita ter qualquer similaridade com o que significa. Opondo-se à ideia de que as palavras são nomes das coisas e as próprias coisas são os significados das palavras, Saussure fez notar que essa concepção decorre do equivocado pressuposto das ideias serem "preexistentes às palavras" (Saussure, 2006, p. 79). Posição igualmente contestada por Vygotsky quando declara existir uma relação direta entre linguagem e pensamento (Vygotsky, 2003). A relação entre as palavras e coisas não provém de uma correspondência um por um, sendo a unidade linguística formada por dois termos psíquicos: "O signo linguístico não une uma coisa e uma palavra, mas um conceito e uma imagem acústica" (Saussure, 2006, p. 80).

Associa-se o termo significado com entendimento dizendo que o indivíduo entende quando ele for capaz de aplicar conhecimentos, conceitos ou habilidades adquiridas em algum tipo de ambiente educacional, em nova situação ou exemplo em que esse conhecimento for relevante e, se não for capaz fazê-lo, por inferência, o indivíduo não entende. Para Gardner (1995) a maioria dos educadores possui dificuldades em definir exatamente a natureza do entendimento ou mesmo nem sabe como documentar se ele foi ou não obtido. Portanto, segundo Gardner, o entendimento é demonstrado através do desempenho do sujeito. É por meio do desempenho de um aprendiz que se pode apreciar e apreender o seu entendimento, não podendo saber se o aluno compreende um princípio de uma ciência estudada, a menos que ele apresente um desempenho relevante de entendimento (Gardner, 1995), e isto implica atuar com sucesso nos conteúdos 
conceituais, procedimentais e atitudinais particularmente relevantes para o ensino das ciências (Zabala, 1998). Então, da possível vinculação entre entendimento e significado pode-se depreender uma forma de avaliá-lo.

Outra aproximação possível ao termo significado é compreensão (ou sentido, saber algo) quando se indaga "qual o significado disso?", ou ao declarar "isto não tem significado", ou ainda ao mencionar "aprendizagem com significado". Entretanto, é possível associar o termo, nesse sentido, a distintos graus de compreensão, variando de uma simples concepção equivocada ou errônea do conhecimento (Clement, 1982) a uma conceituação profunda. Conceituar expressa um entendimento completo e não uma vaga noção do que se está a pensar. Indica uma ideia corretamente estruturada que o ato de aprendizagem conseguiu apropriar-se. Nesse caso emprega-se a palavra conceituar concomitantemente com o termo significado, expressando-se que o conhecimento tem sentido coerente e preciso em relação ao saber oficial, isto é, possuir significado seria, então, afirmar que o conceito ensinado foi apropriado pelo aprendiz. Na próxima seção veremos o ponto de vista semiótico peirceano para o termo significado.

\section{Significado para Peirce}

Do ponto de vista semiótico, ao discutir sobre o significado, Volli (2007) aponta que o significado é um conceito, uma "construção cultural que permite compreender um determinado campo de realidade" (p. 32). Nessa perspectiva, a palavra terra, por exemplo, possui um significado bastante comum, construído culturalmente e dependendo do contexto e da bagagem cultural de determinada pessoa, pode ser empregada tendo em mente solo com características bem diferentes, como a terra-roxa (ou vermelha) que corresponde solo avermelhado bastante fértil presente na região norte do Paraná, ou um solo mais claro e arenoso como o presente na região metropolitana de Campinas (SP), ou ainda tendo em mente o planeta do Sistema Solar denominado Terra.

Para o precursor da semiótica norte-americana, Charles Sanders Peirce (18391914), filósofo, lógico, matemático, físico, astrônomo e químico, o signo é composto de uma relação triádica entre o representamen, aquilo que representa algo para alguém, o objeto, alguma coisa que o signo representa, e o interpretante (Peirce, 2005). Este último termo designa algo que o signo, em sua função significante, essencialmente determina em seu intérprete e, na ausência dele, "algo que seria determinado no intérprete, se ele existisse" (EP2, p.409) ${ }^{1}$, não devendo ser confundido, portanto, com os termos intérprete ou interpretação. Em outras palavras, o interpretante, como será visto, é o efeito que o signo produz e não uma interpretação específica que um intérprete possa a dar ao signo.

Devido à qualidade dual dos objetos, o filósofo americano os categorizou como Objeto Imediato, aquele que o signo representa, e Objeto Dinâmico do signo, sendo o objeto como ele realmente é (Peirce, 2005). O primeiro é o recorte específico do segundo, sendo o modo pelo qual o Objeto Dinâmico é sugerido, referido ou indicado pelo signo.

1 Conforme convenção para estudos da obra de Peirce, EP indica The Essential Peirce: Sellected Philosophical Writings, seguido do volume (ver referências bibliográficas para mais detalhes). 
A imagem vista através de uma janela, por exemplo, é um signo, sendo aquilo que é e não é mostrado por ela seu objeto dinâmico. Como a janela possui limites físicos daquilo que exibe, o enquadramento, isto é, o modo como o objeto dinâmico aparece naquela porção específica, é denominado objeto imediato daquele signo.

Com intuito de refinar a noção de objeto, Peirce desenvolve a ideia de experiência colateral que diz respeito à intimidade prévia do intérprete com aquilo que o signo denota e que, conforme ressaltado pelo semioticista estadounidense, não tem a ver com a familiaridade com o sistema de signos adotado e não faz parte do interpretante (Peirce, 2005). Portanto, todos aqueles que já leram a respeito de elipses, por exemplo, certamente lerão com muito mais facilidade um texto sobre as Estações do Ano (EA), pois já tiveram experiências colaterais com seu o objeto dinâmico. Uma vez que o objeto imediato de certo texto sobre EA tem limites, quer dizer, não pode representar tudo que existe sobre o tópico, aqueles que tiverem interesse em saber mais sobre o assunto podem consultar outros livros, em que encontrarão outros recortes do assunto abordado, como, por exemplo, sobre as equações de uma elipse, ou sobre as Leis de Kepler, ou ainda outros textos sobre as EA, isto é, outros objetos imediatos desse objeto dinâmico que é o conceito das EA.

O terceiro correlato, o interpretante, é aquilo que o signo produz numa quase mente, não sendo nem um simples evento, mas um processo evolutivo, nem resultado de uma atividade subjetiva, e sim uma propriedade objetiva que o signo possui em si mesmo, havendo ou não um ato particular que o atualize ou não (Peirce, 2005). O filósofo americano acrescenta uma terceira classificação com relação ao interpretante, pois a dicotomia encontrada para o objeto "não é suficiente de modo algum" (Peirce, 2005, p. 168), classificando-o em termos das categorias de sua fenomenologia, em Imediato (primeiridade), Dinâmico (secundidade) e Final (terceiridade).

O Interpretante Imediato é tudo aquilo que o signo imediatamente expressa, consistindo em uma qualidade da impressão que um signo está apto a produzir, sendo o interpretante tal como é revelado pela compreensão do próprio signo (CP 4.536; $\mathrm{CP}$ 8.314; CP 8.315) $)^{2}$, sendo uma propriedade objetiva do signo para significar e implica noção de potencial ainda não realizado, possibilidade de interpretação ainda em abstrato, aquilo que o signo está apto a produzir como efeito numa mente interpretante qualquer, isenta de mediação e análise.

O Interpretante Dinâmico é o efeito efetivamente produzido pelo signo na mente do intérprete (CP 4.536; CP 8.315; CP 8.343), e é ainda classificado em Emocional, quando o efeito se realiza como qualidade de sentimento, Energético, efeito é da ordem de um esforço físico ou psicológico, e Lógico, que funciona como uma regra de

2 Conforme convenção para estudos da obra de Peirce, CP indica os Collected Papers (os números indicam o volume, seguindo-se os parágrafos - ver referências bibliográficas para mais detalhes), que são manuscritos de estudos peirceanos que se encontram aos cuidados do Departamento de Filosofia da Universidade de Harvard. Essa universidade publicou, entre 1931 e 1958, os seguintes volumes: I - Princípios da Filosofa; II - Elementos de Lógica; III - Lógica Exata; IV - A mais simples Matemática; V - Pragmatismo e Pragmaticismo; VI - Ciência Metafísica; VII - Ciência e Filosofa; e VIII - Comentários, Correspondência e Bibliografa. 
interpretação (Santaella, 2005a) ${ }^{3}$. Como último estágio, temos o interpretante Final, que seria o resultado semiótico pleno do signo, a norma ou a fronteira ideal e aproximável, mas inatingível, para a qual os interpretantes dinâmicos tendem a caminhar ao longo do tempo (CP 4.536).

Com base no exemplo de signo peirceano da pedra maia de Santaella (2005a), considere o fenômeno de Eclipse Lunar em seu estágio inicial. Mesmo que o evento não seja observado, ou ainda mesmo que seja observado por alguém que, sem nenhum repertório astronômico teórico para compreender esse fenômeno, tome aquilo como uma fase lunar qualquer, o fenômeno não deixaria de ter seu interpretante imediato, interno à sua natureza de signo: ser um fenômeno astronômico apto para ser interpretado como tal. Portanto, o interpretante imediato é uma propriedade objetiva do signo (eclipse lunar) para significar, que advém de seu fundamento, de um caráter que lhe é próprio. Suponhamos que alguém, sem nenhum conhecimento astronômico, esteja olhando para o fenômeno em questão (um signo). Já está evidente no próprio fundamento desse signo que não se trata de um acontecimento qualquer e apresenta propriedades, características e aspectos que a diferenciam de uma fase específica lunar (a porção mais escura está aumentando e a porção iluminada diminuindo em curto espaço de tempo, o que não aconteceria numa "Lua normal"). Há algo nessa visão da Lua (vestígios de que a parte escura aumentou em curto espaço de tempo - seu objeto imediato) que denuncia um contexto fora dela e de que ela faz parte: o evento astronômico Eclipse Lunar (seu objeto dinâmico). As propriedades da visão lunar assim como os vestígios de estar ocorrendo algo a torna apta a ter seu fenômeno decodificado, sendo, inclusive, interpretada como um evento astronômico diferente (interpretante imediato). Entretanto, se o observador jamais teve contato com a teoria astronômica envolvida ou jamais tenha observado ou ouvido falar em tal evento, tal interpretação não será atualizada. Não significa, porém, que nenhum interpretante será produzido, pois existem vários efeitos interpretativos que um signo pode produzir. $\mathrm{O}$ fenômeno pode produzir naquele intérprete desavisado qualidades de sentimento: puro encantamento ou, ainda, medo (pois a lua está sumindo!) com o que está sendo presenciado, isto é, seu interpretante dinâmico emocional. Mas a observação pode produzir também curiosidade em relação ao seu motivo, o que impele o intérprete a uma busca da compreensão da respectiva ocorrência, seu interpretante dinâmico energético. Tendo por base esse esforço, guiado por um raciocínio lógico, o intérprete pode chegar à conclusão de que o fato da parte escura da Lua estar aumentando em curto espaço de tempo é um sinal dos deuses ou que ela esteja sendo engolida por algo grandioso, isto é, seu interpretante dinâmico lógico.

Ao invertermos o caráter desse intérprete, isto é, o observador seja um astrônomo amador ou profissional, especialista em Sistema Solar. Independentemente desse fenômeno específico, o intérprete tem extensa familiaridade (experiências colaterais)

3 A inserção da segunda tríade dos interpretantes (Emocional, Energético e Lógico) no interpretante Dinâmico ainda é alvo de discussões entre os estudiosos de Peirce e não faz parte dos objetivos do presente trabalho, que irá considerar a visão de Santaella (2004; 2005a; 2005b). Para mais detalhes sobre o assunto ver, por exemplo, Santaella (2004), Johansen (1985; 1993), Buczynska-Garewicz (1981) e Savan (1976). 
com o objeto dinâmico desse signo, nos conhecimentos que acumulou ao longo de sua experiência com fenômenos astronômicos, habilidade para prever e observar eclipses lunares e solares, dentre outros fenômenos astronômicos. Nesse caso, o interpretante dinâmico lógico vem cedo demais. O intérprete domina as regras interpretativas daquele fenômeno. $O$ fundamento do signo agora é um suporte de leis de representação que fazem com que o fenômeno seja interpretado, o intérprete tem o hábito adquirido de decodificar tal acontecimento não mais como formas, meros sinais, mas como representação. Ressalta-se que, para esse intérprete, os interpretantes emocional e energético existem, mas tornam-se imperceptíveis. E o interpretante final Peirceano seria o efeito que o fenômeno do Eclipse Lunar (o signo) produziria em qualquer mente se fosse possível que o signo pudesse produzir todos os interpretantes dinâmicos de modo exaustivo e final, isto é, se a semiose fosse levada suficientemente longe.

Com relação ao problema do que seja o significado de um conceito intelectual, Peirce afirma que a sua solução passa pela ideia dos interpretantes ou, mais propriamente, dos efeitos interpretantes dos signos, em que este é parte constituinte do signo que afeta a mente, determinando ou criando-lhe um efeito (Peirce, 1980). Com esse conceito, estabelece que o processo de significação é sempre contínuo, crescente e dirige-se para o conteúdo objetivo do signo, parte do que Peirce denominou de "Teatro das Consciências" (EP2, p. 403). Portanto, considerar quais efeitos interpretantes são concebidos frente ao objeto da percepção é conhecer qual significado é dado a um signo. E ao dar entendimento da representação como um fenômeno semiótico, muda-se a visão da relação entre representação e significado, conforme dito na introdução, e a utilização de uma Diversidade Representacional como referencial metodológico possui papel fundamental, conforme será vista na próxima seção.

\section{Diversidade Representacional}

Alguns pesquisadores utilizam o modelo triádico de signo peirceano na área da educação científica (Tytler, \& Prain, 2013; Waldrip, Prain, \& Carolan, 2010), fazendo-se distinções entre uma representação em um signo ou significante (e.g., um desenho de um fluxograma de energia; ou setas numa explicação diagramática de forças), a interpretação ou sentido dado a esse signo por um intérprete (a ideia científica de energia; ou a ideia científica de força), e seu referente, ou o fenômeno que tanto a interpretação quanto o significante referem-se (exemplos de operação da energia em objetos no mundo; ou exemplos de operações de força em objetos no mundo). E a cada nova interpretação de uma representação reativa uma nova interação dessa tríade, tornando-se uma nova interpretação de uma interpretação já existente (Tytler, \& Prain, 2013; Waldrip, Prain, \& Carolan, 2010). Segundo Waldrip, Prain e Carolan (2010), os alunos, ao se envolverem com significados científicos ainda não vistos, devem reconhecer as diferenças entre a ideia (ou conceito), as diferentes formas de representar essa ideia e os fenômenos a que se refere. Isso implica que todas as tentativas de compreensão ou explicação realizadas pelos estudantes de conceitos científicos implicam em um trabalho representacional que 
necessita que esses aprendizes utilizem seus atuais recursos cognitivos e representacionais para dar sentido a conceitos científicos que são novidades para eles, e que são reiterados em novas representações que devem ser interpretadas novamente. Em outras palavras, vir a conhecer o que significa o conceito científico de força ou de energia implica na compreensão e no uso apropriado de recursos representacionais para a realização de ligações cognitivas entre o fenômeno, teoria e relatos científicos apropriados (Tytler, \& Prain, 2013).

A linha de pesquisa científica do referencial das Múltiplas Representações e Multimodalidade Representacional concentra esforços para a compreensão e instigação dos significados dos conceitos científicos pelos estudantes. A literatura preocupase muito pouco em relação ao esclarecimento das diferenças entre as definições de Multimodos e Múltiplas representações (Laburú, Zompero, \& Barros, 2013). O termo Múltiplas Representações designa a capacidade de se representar um mesmo conceito (ou processo) científico de diversas maneiras (Prain, \& Waldrip, 2006; Tytler, Prain, \& Peterson, 2007), enquanto que o termo Representações Multimodais refere-se à integração de diferentes modos no discurso científico do raciocínio e descobertas científicas, isto é, faz alusão ao fato que a aprendizagem com uma ou mais representações geralmente integra diversos componentes de várias modalidades como texto verbal, figuras e equações (Prain, \& Waldrip, 2006). No presente trabalho iremos considerar ambos os termos como sinônimos, e denotar as variadas classificações dos modos de representação como Diversidade Representacional.

Variadas pesquisas recentes têm afirmado que, para haver aprendizagem efetiva de ciências, os aprendizes precisam trabalhar com uma Diversidade Representacional dos conceitos e processos científicos e serem capazes de traduzi-las umas nas outras, assim como entender seu uso coordenado na representação do conhecimento científico (Wallace, Hand, \& Prain, 2004). Ainsworth (1999; 2006; 2008) propõe uma taxonomia funcional das Múltiplas representações que considera que o comprometimento com as múltiplas representações apoia a aprendizagem através de três formas: (i) diferentes representações complementam-se apresentando diferentes aspectos do mesmo fenômeno; (ii) quando a nova representação restringir a interpretação de outras, limitando o foco do aprendiz sobre conceitos chave fundamentais pois muitas vezes o aprendiz considera a nova representação muito complexa ou abstrata, então a utilização de outras representações mais familiares e concretas pode auxiliar na compreensão do fenômeno; ou (iii) quando aprendizes conseguem relacionar as representações para identificar quais são as características invariantes compartilhadas de um domínio e quais as propriedades das representações individuais, ou seja, o estudante constrói um maior entendimento ao integrar informações de mais de uma representação (Sutopo, \& Waldrip, 2014). Elas ainda podem ser complementadas com mais duas: (iv) os aspectos de adequação, em que certos modos podem se adequar melhor a determinados indivíduos, e (v) emocional, pois cada aprendiz mantém uma relação de ordem emocional própria com o conhecimento (Laburú, \& Silva, 2011b). 
As variadas classificações dos modos de representação que têm sido propostas nos últimos anos são categorizadas em descritivas (verbal, gráfica, tabular, diagramática, matemática), figurativas (pictórica, analógica ou metafórica), cinestésicas ou de gestos corporais (encenação, jogos), que utilizam objetos tridimensionais (3D), experimentais ou maquetes (Laburú, \& Silva, 2011a). Sobre a relação entre aprendizagem e representações, esses pesquisadores afirmam que a combinação destas (representações) com um discurso científico integrador baseado em múltiplas representações constitui um mecanismo pedagógico de suma importância, aprimorando o processo de significação e oferecendo procedimentos variados de interpretação e entendimento (Laburú, \& Silva, 2011b).

\section{Instrumento Analítico}

A linguagem científica pode ser vista como um grande signo complexo, constituída de diversos outros signos formados por ideias, símbolos, conceitos, teorias, procedimentos, entre outros. Para que seja possível a identificação dos níveis (ou graus) de significado que detalhem o estado transitório do conhecimento do estudante, propomos uma reformulação da tricotomia interpretante adequando-a para uma leitura com fins pedagógicos. Devido às peculiaridades existentes em qualquer situação exequível de ensino e de interesse pedagógico, um afastamento das demarcações e enunciações peirceanas se faz necessário. Nessa perspectiva, a transposição dos termos técnicos peirceanos nos liberta de uma maior fidelidade e rigor de seus conceitos, além de nos impor um distanciamento seguro de seus condicionantes sem tornar suas origens irreconhecíveis. O instituto interpretante pretendido no presente trabalho tem a intenção de caracterizar os significados da aprendizagem dos alunos sem literalidade, mas por afinidade ou correspondência com as proposições do semioticista estadounidense. Portanto, devido à impossibilidade de reduzir as ideias peirceanas a uma concepção estreita, circunstancial ou situacional ligada a possíveis particularidades educacionais, esse afastamento stricto sensu se faz necessário.

Tal instrumento pode auxiliar o professor na árdua tarefa de acompanhamento da produção e desenvolvimento dos significados adquiridos pelos estudantes enquanto estes o fazem durante o processo de ensino, possibilitando o direcionamento e enquadramento ao conhecimento científico. Tomando a classificação dos interpretantes de Peirce adotada por Santaella (2004; 2005a; 2005b), em que a segunda tríade (emocional, energético e lógico) está inserida somente no interpretante dinâmico, obtemos cinco níveis de significado: Nível Significante Imediato, Nível Significante Dinâmico Emocional, Nível Significante Dinâmico Energético, Nível Significante Dinâmico Lógico e Nível Significante Final.

O Nível Significante Imediato é um primeiro resultado do ato de significação estabelecido por um aprendiz frente aos signos científicos. Entre as características apresentadas, ele é equivalente ao significado anterior a qualquer ato de instrução, isto é, o efeito interpretante do estudante se manifesta em significados análogos aos 
anteriores a quaisquer atos educacionais de conteúdos específicos de física, no caso, que permanece circunscrito ao contexto dos conhecimentos prévios, senso comum, aparente, intuitivo do aprendiz. A interpretação fica presa a denotações de primeira ordem, isto é, ao significado interno do signo (e.g., ao utilizar o termo trabalho, em um contexto de aula de física, em alusão a um conjunto de atividades que o homem exerce para atingir determinado fim, ficando preso ao senso comum). Transpondo para o caso do Ensino de Astronomia, temos, nesse nível, o uso de "chavões" (Bisch, 1998, p. 225) sobre concepções de astronomia de alunos e professores, que podem ser chavões verbais, no caso de enunciados, e gráficos, no caso de imagens. Segundo o referido pesquisador, "a fundamentação desses chavões nunca é explicitada, seu conteúdo não é questionado, submetido à crítica mediante o cruzamento e comparação com outros conhecimentos ou dados da realidade." (Bisch, 1998, p. 226), isto é, uma resposta seca dada de forma mecânica que ele provavelmente leu em algum material ou ouviu em sala de aula em algum momento, e a utiliza sem convicção e sem a realização de uma reflexão pormenorizada dos elementos envolvidos no conceito em questão.

Ao ultrapassar o primeiro nível, chega-se ao Nível Significante Dinâmico, que seria equivalente ao significado que o signo provoca numa mente estimulada por interferências de ensino. Quanto aos efeitos interpretantes produzidos no intérprete, subdivide-se em Emocional, Energético e Lógico, sendo que a relevância relativa do significado de cada um desses três interpretantes mantém-se na dependência do tipo de conteúdo tratado. Neste interpretante, o processo de conotação sígnica é desencadeado e deslocado da denotação de primeira ordem em razão de novas significações que começam a se instaurar na mente por causa da circunstância instrucional. Há, portanto, no presente nível, conotação ou denotação de enésima ordem, pois o significado provém de enésimos sentidos assentes sobre a primeira denotação (Barthes, 1999; Eco, 1985; Presmeg, 2006), cuja significação original se mantinha no nível significante inicial. Isto é, as significações acumuladas ou transformadas, oriundas de variados momentos instrucionais, tornam-se gradualmente diferenciadas do primeiro nível, referente ao Interpretante Imediato.

No Nível Significante Dinâmico Emocional o efeito interpretante apresenta qualidade de sentimento, sendo reconhecido quando os estudantes exibem significados confusos (contraditórios, opacos, indeterminados, ambíguos, hesitantes, presos à beleza e opiniões emocionais) e/ou etéreos (transcendentes, de caráter religioso, metafísico, místico ou mítico). É importante ressaltar que esse é o efeito interpretante produzido pelo signo que está por detrás de um conteúdo científico específico, o que implica que ele precisa ser compreendido a partir do enquadramento do conteúdo específico em foco, em vez de genéricos estados de sentimento ou disposição psicológica (emoção, afetividade, desejo, motivação, ansiedade, antipatia pelo professor, entre outros). Quando tais qualidades não permanecem circunscritas a fatores de ordem exclusivamente psicológicos e sim provocadas pelo que o signo significa para o sujeito, com consequente interferência cognitiva ligada ao conteúdo, essas qualidades são atribuídas ao nível 
Significante Dinâmico Emocional.

ONível Significante Dinâmico Energético éo efeito devido a atos de interpretação, caracterizado por esforços musculares dos estudantes, isto é, comportamentos, atitudes, procedimentos, técnicas originadas do processo educacional, traduzidos em signos emitidos através da ação, gestos, atos e expressões. É comum esse nível significante se apresentar via emissão de signos expressivos visuais (Eco, 1985), os quais não têm o propósito direto de comunicar, pois costumam ser espontâneos, involuntários e intuitivos, visto escaparem à codificação consciente. Tais signos expressivos surgem de forma subliminar nas ações ou gestos existentes nos comportamentos, atitudes, procedimentos e técnicas. Entretanto, quando emitidos intencionalmente, se corretos ou incorretos, tornam-se signos comunicativos (Eco, 1985), visto terem sido produzidos artificialmente, no sentido de provocados por meio da instrução. O presente nível será analisado no presente trabalho em termos de sua coerência com o cientificamente aceito.

No seguinte nível, denominado Nível Significante Dinâmico Lógico, o ato de significação é estabelecido por um efeito efetivamente produzido em um aprendiz frente aos signos científicos que se mostra expresso junto aos signos comunicativos em meio a regras interpretativas formais e normativas que têm por base o conteúdo eminentemente conceitual. Ao contrário do que acontece no nível imediato, o presente nível caracterizase pela interpretação de signos através do domínio de novas regras internalizadas pelo intérprete que auxiliam a fazer inferências e estabelecer consequências de premissas. Essas regras conectam o signo a outros objetos e signos do conhecimento científico de maneira unívoca, sem admissibilidade de equívoco. O efeito interpretante se dá por função semântica e base sintática, estando associado aos modos de expressão, significado e sentido dos termos utilizados pela nova concepção e que permite construir e identificar representações, imagens e proposições coerentes, internamente consistentes e inter-relacionadas. Opondo-se aos signos de função estética, no presente nível eles são rigidamente estruturados, traduzíveis e demandam respostas ativas dirigidas a objetivos explícitos, por isso, mantêm acentuada função semântica. Com respeito à determinação precisa do significado, esta função prepara para a ação, portanto, para a observação, experimentação e conduta precisa, motivo pelo qual esses signos têm que ser únicos, em termos do compartilhamento de seu significado, para facilitar a comunicação e conferir ou ratificar as teorias propostas (Epstein, 2002). A princípio, os signos unívocos (Eco, 1985) usados na ciência, ao preparem para ação objetiva, não deveriam ter dissociados seus efeitos interpretantes Lógico e Energético. Efetivamente, os três Níveis Significantes Dinâmicos coexistem com predominância relativa entre si, estando suas supremacias na dependência da evolução do entendimento alcançado, da natureza ontológica do tema tratado e da relação que mantêm com as características tipológicas do conteúdo que está sendo estudado, seja ela conceitual, procedimental ou atitudinal (Zabala, 1998).

Não confundindo com o interpretante homônimo peirceano, como dito anteriormente, o Nível Significante Final é aquele idealizado pelo professor e balizado pelos documentos oficiais da educação, onde o signo apreendido torna-se parte 
integrante de um conhecimento normatizado e o significado independe do intérprete, consistindo na maneira pela qual toda mente deveria pensar e agir em conformidade ao conhecimento oficial. Neste estágio, há mudança de hábito e conduta, desprendendose do aspecto denotativo e estabelecendo análises conotadas com foco no que está institucionalizado pelo signo. Este nível é caracterizado pela produção de inferências, avaliações, generalizações, seleções e comparações aplicáveis do efeito desejado e o entendimento é apreciado pela conjunção coordenada dos níveis Significantes Lógico e Energético, e pela convivência harmônica (ou não mais conflituosa), do ponto de vista do aprendiz, com o Nível Significante Emocional. Portanto, a significação completa atingida nesse nível significante de um sujeito reúne todos os efeitos interpretantes que o professor tem em vista, vindo da somatória das lições acerca do signo, dos resultados capazes de afetar a conduta e dos objetivos pretendidos para com o aprendiz.

\section{Componentes conceituais básicos das Estações do Ano}

Segundo Lelliott e Rollnick (2010), a causa das EA na Terra pode ser explicada cientificamente por meio de quatro conceitos fundamentais: (i) a órbita anual da Terra em torno do Sol, (ii) a inclinação de $23,5^{\circ}$ do eixo de rotação do planeta em relação à normal ao plano de translação da Terra em torno do Sol; (iii) a natureza esférica da Terra, e suas (iv) consequentes alterações na intensidade da radiação do Sol que atinge a superfície do planeta, devido à inclinação e órbita mencionadas anteriormente. Devido à inclinação mencionada, à medida que o nosso planeta orbita o Sol, os raios solares incidem mais diretamente em um hemisfério ou outro, proporcionando mais horas com luz durante o dia a um hemisfério ou outro e, portanto, aquecendo mais um hemisfério ou outro (Figura 1). No Equador todas as estações são semelhantes e todos os dias do ano o Sol fica 12 horas acima do horizonte e 12 horas abaixo dele, e a única diferença é a máxima altura que ele atinge (Oliveira Filho, \& Saraiva, 2004).

Adaptando os componentes das EA elencados por Lelliott e Rollnick (2010), para a nossa análise científica das representações verbais textuais, iremos considerar três componentes fundamentais básicos: (i) [CEA1]: representações verbais textuais relacionadas à órbita anual da Terra em torno do Sol; (ii) [CEA2]: representações verbais textuais relacionadas aos $23.5^{\circ}$ de inclinação do eixo de rotação da Terra em relação à normal de sua órbita; e (iii) [CEA3]: representações verbais textuais relacionadas à natureza esférica da Terra, e consequentes alterações na intensidade da radiação do Sol que atinge a superfície.

Com relação às representações imagéticas das EA, iremos considerar os seguintes componentes fundamentais básicos, que podem ser visualizados na figura 2: (i) [IMEA1]: identificação hemisférios Norte e Sul; (ii) [IMEA2]: identificação do ângulo de inclinação do eixo de rotação da Terra (aproximadamente $23,5^{\circ}$ do eixo de rotação da Terra em relação à normal ao plano de órbita da Terra em torno do Sol e/ou ângulo de aproximadamente $23,5^{\circ}$ do equador celeste em relação à eclíptica) e eixo apontando sempre para mesma direção; (iii) [IMEA3]: Identificação da direção de revolução da 
translação da terra em torno de Sol: sentido anti-horário com o Norte da Terra para cima (Gregersen, 2010, p. 109-111); (iv) [IMEA4]: Identificação dos equinócios e solstícios para os hemisférios Norte e Sul (ou identificação de posições da Terra em que seja verão, outono, inverno e primavera nos respectivos hemisférios); e (v) [IMEA5]: Menção de a figura encontrar-se fora de escala.

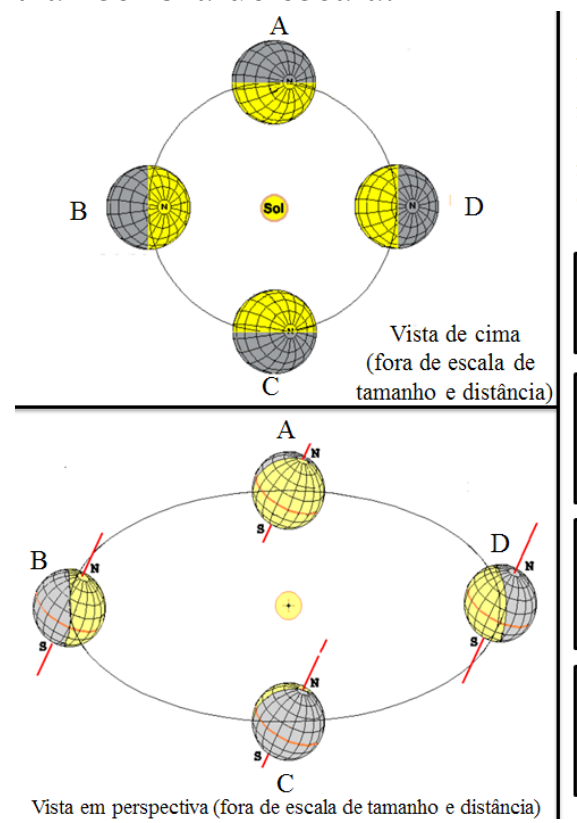

A Terra apresenta Estações do Ano devido à inclinação do seu eixo de rotação. A Terra

rotaciona em torno do seu eixo enquanto orbita o

Sol numa órbita quase circular (cf. vista de cima),

mas o eixo de rotação aponta sempre para mesma

direção (cf. vista em perspectiva).

Posição A: Março, outono ao sul do equador, primavera ao norte do equador. O Sol brilha igualmente para os hemisférios norte e sul.

Posição B: Junho, inverno ao sul do equador, verão ao norte do equador. O Sol brilha diretamente no hemisfério norte e indiretamente no hemisfério sul.

Posição C: Setembro, primavera ao sul do equador, outono ao norte do equador. O Sol brilha igualmente para os hemisférios norte e sul.

Posição D: Dezembro, verão ao sul do equador, inverno ao norte do equador. O Sol brilha diretamente no hemisfério sul e indiretamente no hemisfério norte.

Figura 1. Representação Imagética dos reais motivos das Estações do Ano na Terra. (Adaptado de $<$ http://www.cdcc.usp.br/cda/producao/sbpc93/>, acesso realizado em 07/10/2016)

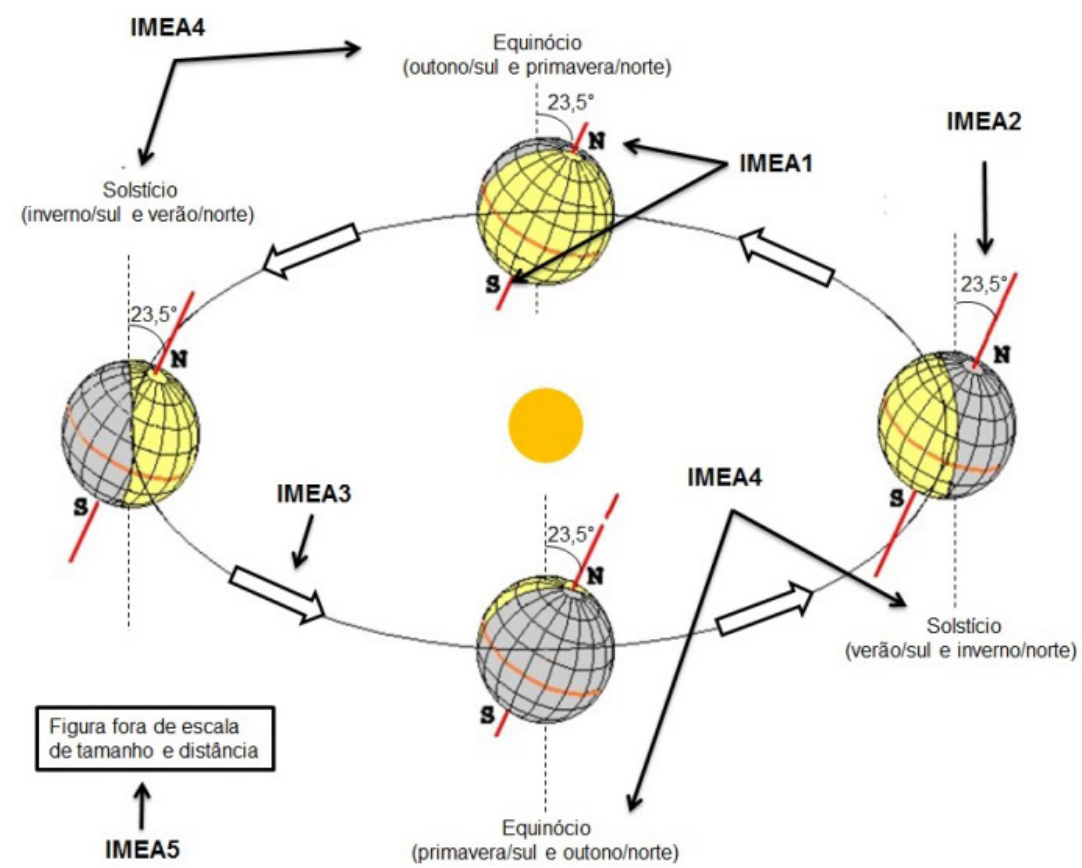

Figura 2. Identificação das componentes imagéticas essenciais das EA na representação imagética (adaptado de <http://www.cdcc.usp.br/cda/producao/sbpc93/>, Acesso realizado em $07 / 10 / 2016)$ 


\section{Metodologia}

O presente trabalho, de cunho qualitativo, faz parte de uma investigação mais ampla, que pretende responder a questão de pesquisa de qual nível de significado, através do nível significante predominante, os estudantes de graduação de Ciências Biológicas atingem na utilização de uma Diversidade Representacional sobre temas astronômicos. A pesquisa foi realizada entre novembro de 2015 e fevereiro de 2016 durante a disciplina de física para licenciatura em Ciências Biológicas de uma universidade estadual do sul do Brasil. A ementa da disciplina em questão engloba conceitos gerais de astronomia desde 2010.

O perfil socioeconômico dos estudantes do curso que participaram dessa pesquisa não diferencia muito do restante das instituições estaduais de ensino superior do Brasil ${ }^{4}$. A maioria dos estudantes $(89,7 \%)$ do curso frequentou todo o ensino de nível médio em escola pública. Grande parte dos estudantes $(51,7 \%)$ fazem parte de famílias com renda total de até 3 salários mínimos. Apesar de todas as adversidades, o referido curso participante da pesquisa foi bem avaliado na última avaliação do Instituto Nacional de Estudos e Pesquisas Anísio Teixeira - INEP, de 2014, obtendo faixa 4 no ENADE e faixa 3 do Conceito Preliminar de Curso.

Todos os 35 estudantes da referida disciplina participaram da proposta de utilização de Diversidade Representacional para o ensino de conteúdos de astronomia. Destes, 18 fizeram parte da pesquisa, chamando-os de E01 a E18, conforme ordem aleatória dos mesmos, para efeito de sigilo, que realizaram todas as atividades e concordaram em fazer parte da mesma, assinando um termo de consentimento livre e esclarecido.

Foi utilizado um total de 16 aulas para a intervenção didática. A figura 3 resume o cronograma de atividades, ações e modo representacional das ações desenvolvidas.

Inicialmente, o professor-pesquisador realizou um teste nas duas primeiras aulas (A1), por meio de um questionário contendo algumas questões de múltipla escolha e outras que solicitavam a realização de representação imagética e/ou textual de fenômenos astronômicos, denominado Teste Diagnóstico, com intuito de constatar se a turma (ou parte dela) havia realizado algum tipo de curso de Astronomia ou algo parecido, e de verificar em qual nível significante inicial os pesquisados se encontravam com relação ao conteúdo das Estações do Ano. Em outras palavras, em A1 os estudantes produziram representações textuais e imagéticas individuais acerca das Estações do Ano, para a verificação dos níveis significantes iniciais demonstrados pelos aprendizes.

As quatro aulas seguintes (A2 e A3) foram destinadas a exposições em slides, em que os alunos tiveram contato com representações verbal oral, textual, imagéticas e tabulares produzidas pelo professor sobre a composição e escalas de tamanho e distância do Sistema Solar.

Nas duas aulas seguintes (A4), na prática denominada "Sistema Solar em Escala", os alunos produziram em grupos representações $3 \mathrm{~d}$ a respeito das escalas de tamanho e distância do Sol, planetas e satélites do Sistema Solar. Foram utilizados materiais de

4 Fonte: <http://enadeies.inep.gov.br/enadeIes/enadeResultado/>, acesso realizado em 27/08/2016. 
baixo custo e de fácil acesso, incluindo bexiga gigante para representação do Sol, massa de modelar, barbante, transferidor e régua, entre outros.

Nas aulas subsequentes (A5), os alunos tiveram contato com apresentações expositivas a respeito das Estações do Ano e Eclipses, trabalhando-se modos representacionais verbal oral, textual, imagético e tabular produzidas pelo professor.

Nas duas aulas seguintes (A6) foi realizada a prática "Órbita da Terra e as Estações do Ano”. Nela, os estudantes construíram, em grupos, representações imagéticas da órbita em escala da trajetória da Terra em torno do Sol e, em conjunto, representações 3d de seis posições do movimento anual da Terra para o estudo das Estações do Ano. Para a realização dessa prática, dois estudantes foram previamente escolhidos, aleatoriamente, para o estudo dos seus respectivos níveis significantes dinâmicos energéticos: E04 e E17. Além disso, foram utilizadas placas de isopor para a representação da órbita, esferas de isopor e palitos de churrascos para a representação da Terra e seu eixo de rotação, respectivamente, e lâmpadas para fazerem o papel da radiação solar.

As quatro últimas aulas (A7) ficaram reservadas para a coleta dos dados finais, em forma de avaliação, denominado Teste Avaliativo, solicitando-se aos alunos que realizassem representações textuais e imagéticas sobre as Estações do Ano. No atual recorte selecionamos os dados produzidos por três estudantes (E02, E04 e E17) em dois momentos distintos, obtidos em A6 (Prática Órbita da Terra e Estações do Ano) e A7 (Teste Avaliativo).

\begin{tabular}{|l|l|l|}
\hline $\begin{array}{l}\text { Referência - Data } \\
\text { (no de aulas) }\end{array}$ & Ações & $\begin{array}{l}\text { Modo Representacional } \\
\text { Dominante }\end{array}$ \\
\hline A1 - 23/11/2015 (02) & Teste Diagnóstico & $\begin{array}{l}\text { Textual e imagético produzido } \\
\text { pelos estudantes individualmente }\end{array}$ \\
\hline A2 - 23/11/2015 (02) & $\begin{array}{l}\text { Aulas expositivas: Sistema Solar: } \\
\text { composição e escalas de tamanho e } \\
\text { distâncias }\end{array}$ & $\begin{array}{l}\text { Verbal oral, textual, imagético e } \\
\text { tabular produzido pelo professor }\end{array}$ \\
\hline A3 - 30/11/2015 (02) & $\begin{array}{l}\text { Aulas expositivas: Sistema Solar: } \\
\text { composição e escalas de tamanho e } \\
\text { distâncias (continuação) }\end{array}$ & $\begin{array}{l}\text { Verbal oral, textual, imagético e } \\
\text { tabular produzido pelo professor }\end{array}$ \\
\hline A4- 07/12/2015(02) & Prática Sistema Solar em Escala & $\begin{array}{l}\text { 3d produzido pelos estudantes em } \\
\text { grupos }\end{array}$ \\
\hline A5 - 01/02/2016 (02) & $\begin{array}{l}\text { Aulas expositivas: Estações do Ano e } \\
\text { Eclipses }\end{array}$ & $\begin{array}{l}\text { Verbal oral, textual, imagético e } \\
\text { tabular produzido pelo professor }\end{array}$ \\
\hline A6 - 15/02/2016 (02) & $\begin{array}{l}\text { Prática Órbita da Terra e as Estações } \\
\text { do Ano }\end{array}$ & $\begin{array}{l}\text { Imagético e 3d produzido pelos } \\
\text { estudantes em grupos }\end{array}$ \\
\hline A7 - 22/02/2016(04) & Teste Avaliativo & $\begin{array}{l}\text { Textual e imagético produzido } \\
\text { pelos estudantes individualmente }\end{array}$ \\
\hline
\end{tabular}

Figura 3. Cronograma de atividades, conteúdo e modo representacional para as atividades desenvolvidas 


\section{Resultados e Discussões}

Para as discussões, foram levados em conta três casos distintos, simulando possíveis acontecimentos em sala de aula. O primeiro relata o caso em que pode ser observados indícios da construção sígnica, seja por meio de representações verbais ou não-verbais no ato de sua elaboração, isto é, em que pode-se observar o Nível Significante Dinâmico Energético gerado pelo estudante. No segundo caso simula-se a situação em que tais indícios não puderam ser acompanhados. Relata-se no último, o caso em que o estudante conseguiu atingir predominantemente o último Nível Significante.

Todos os estudantes analisados no presente recorte apresentaram Nível Significante Imediato sobre as EA no Teste Diagnóstico (Trevisan Sanzovo, \& Laburú, 2016), seja explicando o fenômeno através da concepção alternativa mais difundida desse conceito (distância Terra-Sol - casos de E02 e E17), ou com uso de chavões (caso de E04).

\section{Caso 1}

Para o primeiro caso, relata-se o estudo dos níveis significantes apresentados por um estudante quando se é possível observar e acompanhar indícios da produção sígnica no ato de sua construção, isto é, em que é possível observar o Nível Significante Dinâmico Energético. No caso de E04, tal nível pode ser observado na atividade da construção da maquete na Prática "Órbita da Terra e as Estações do Ano".

Durante a mesma, E04 mediu em um barbante um comprimento de arco de $23,5^{\circ}$ em cima de um transferidor, marcou essa distância na Terra (esfera de isopor) em ambos os polos e retirou o palito de churrasco que representaria o eixo de rotação da Terra (Figura 4).

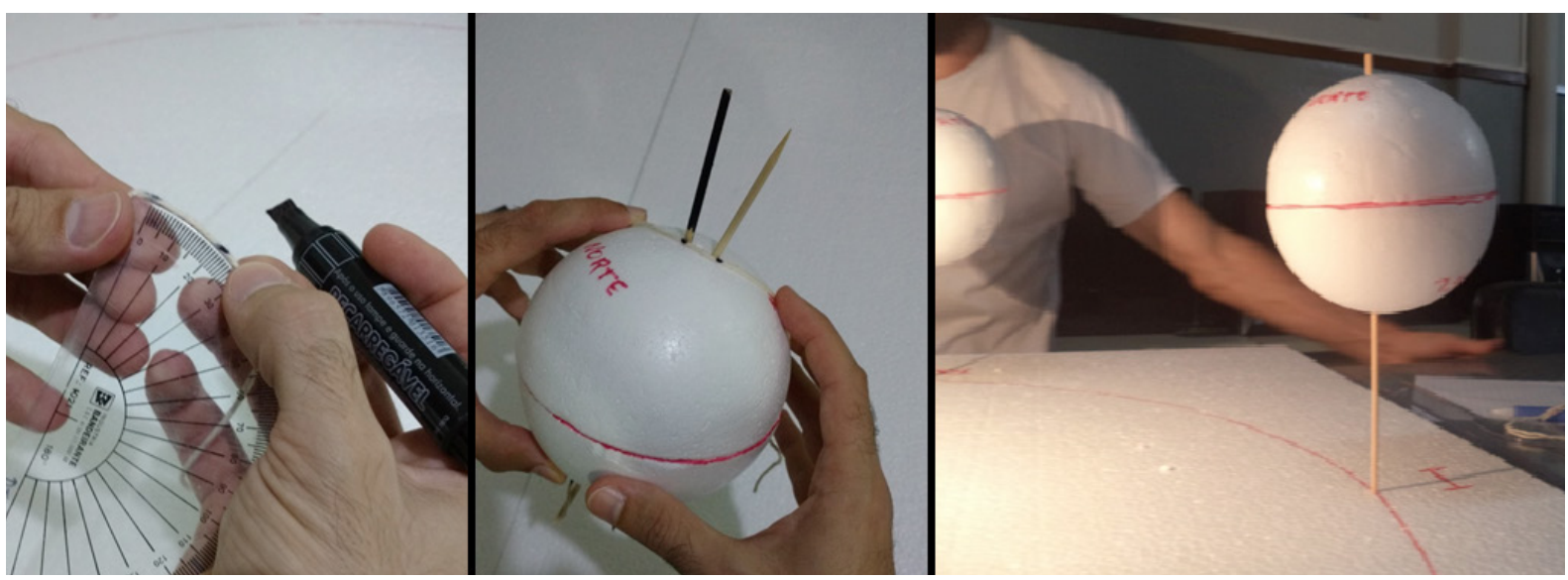

Figura 4. Interpretante Dinâmico Energético de E04 na prática da maquete das EA

Ou seja, o palitinho de churrasco não representa mais o eixo de rotação da Terra para o grupo de E04, apesar de o professor ter deixado claro que deveria representar (uma mesma posição na Terra construída dessa maneira, como por exemplo, São Paulo, receberia incidência de raios solares típicos de cada uma das EA numa única rotação). 
Segundo Prain e Waldrip (2006), o sucesso do aluno em realizar a construção de um modelo $3 \mathrm{~d}$ não significa necessariamente que ele compreendeu os princípios subjacentes do conceito estudado. Levanta-se então a questão sobre a diferença entre aquisição (ou domínio de uma competência) e aprendizagem (ou de conhecimento consciente) proposta por Gee (2008), pois enquanto que alguns recursos e tecnologias promovem a aquisição de competências, que pode ser uma parte importante do desenvolvimento da aprendizagem, o domínio dessa competência em si não significa automaticamente aprendizagem em ciência. Em termos semióticos, se o aluno constrói uma representação textual coerente que atinge um Nível Significante Dinâmico Lógico, em conjunto com a maquete do exemplo mencionado ou, ainda, associada a uma representação imagética das EA, de maneira correta em termos científicos, pode ser dito que o Nível Significante Dinâmico Energético apresentado está condizente com (mas não implica em) uma aprendizagem adequada do conceito envolvido. E, conforme visto anteriormente, para chegar ao último nível de significado, caracterizado pelo modo no qual toda mente deveria agir e pensar em conformidade com o conhecimento oficial, é preciso haver um entendimento apreciado pela conjunção coordenada dos Níveis Significantes Lógico e Energético, e pela convivência harmônica (ou ao menos não mais conflituosa), do ponto de vista do aprendiz, com o Nível Significante Emocional. Portanto, para esse caso, iremos dizer que o Nível Significante Dinâmico Energético apresentado pelo estudante é coerente com um possível Nível Significante Final. Agora, ao realizar a construção da referida maquete ou uma representação imagética de forma cientificamente equivocada, pode-se dizer que o Nível Significante Dinâmico Energético apresentado pelo estudante não está condizente com a aprendizagem adequada do conceito científico, indo numa direção contrária ao conhecimento idealizado pelo professor e balizado pelo currículo, isto é, distanciando-se de um possível Nível Significante Final. Para este último caso, denotaremos o Nível Significante Dinâmico Energético como sendo não coerente com relação a um possível Nível Significante Final, que é o caso de E04.

Essa não harmonização é demonstrada no teste avaliativo de E04, em que não chega a atingir o último nível. No referido teste, E04 produziu a seguinte representação textual sobre as EA:

As Estações do Ano é um fenômeno que tem como causa a inclinação de $23,5^{\circ}$ do eixo de rotação da Terra em relação ao equador celeste. Esta inclinação faz com que os raios solares tenham maior incidência num dos polos em determinadas épocas do ano em relação ao outro polo terrestre, esta diferença de radiação solar chega ha(sic) $45 \%$ a mais de radiação no polo que se encontra no verão, e na mesma época, o polo oposto, se encontra no inverno (representação textual de E04 para o Teste Avaliativo).

Percebe-se claramente que essa representação apresenta um significado equivalente àquele estimulado por interferências de ensino, pois apresenta os componentes fundamentais [CEA2] e [CEA3]. E04 conclui que os raios solares têm "maior incidência" em diferentes pontos da Terra devido à "inclinação de $23,5^{\circ}$ do 
eixo de rotação da Terra em relação ao equador celeste". Com relação à representação imagética, apresenta o componente fundamental [IMEA1] invertido (geralmente o padrão é colocar o Norte em cima e o Sul embaixo), o que não acarreta nenhum problema, pois não identifica o ângulo na figura [IMEA2] e nem a direção de translação [IMEA3], conforme ilustrada pela figura 4. Apresenta de forma parcialmente correta, em termos científicos, assim como o fez no Teste Diagnóstico, o componente [IMEA4], pois parece repetir outono e primavera num mesmo hemisfério ao longo de um ano. Analisando ambas as representações (textual e imagética), E04 apresenta representações científicas coerentes e internamente consistentes e inter-relacionadas, construídas de maneira lógica, atingindo um significado predominantemente de Nível Significante Dinâmico Lógico.

Além da não coerência do Nível Significante Dinâmico Energético para a atividade prática das EA, distanciando-se de um possível Nível Significante Final, o significado apresentado por E04, cientificamente falando, claramente não é o significado idealizado pelo professor e balizado pelo currículo, pois na representação imagética no Teste Avaliativo não identifica o ângulo da inclinação, além de não identificar explicitamente em quais posições seria primavera ou outono nos respectivos hemisférios (Norte e Sul), e apresentar um dado equivocado como exemplo na representação textual, pois temos, por exemplo, uma diferença de aproximadamente $45 \%$ e $66 \%$ na iluminação recebida durante o Verão e Inverno para as cidades de São Paulo e Porto Alegre, respectivamente (Horvath, 2008; Oliveira Filho, \& Saraiva, 2004). Além disso, o significado apresentado não independe do intérprete (é apenas o significado singular exposto por E04).

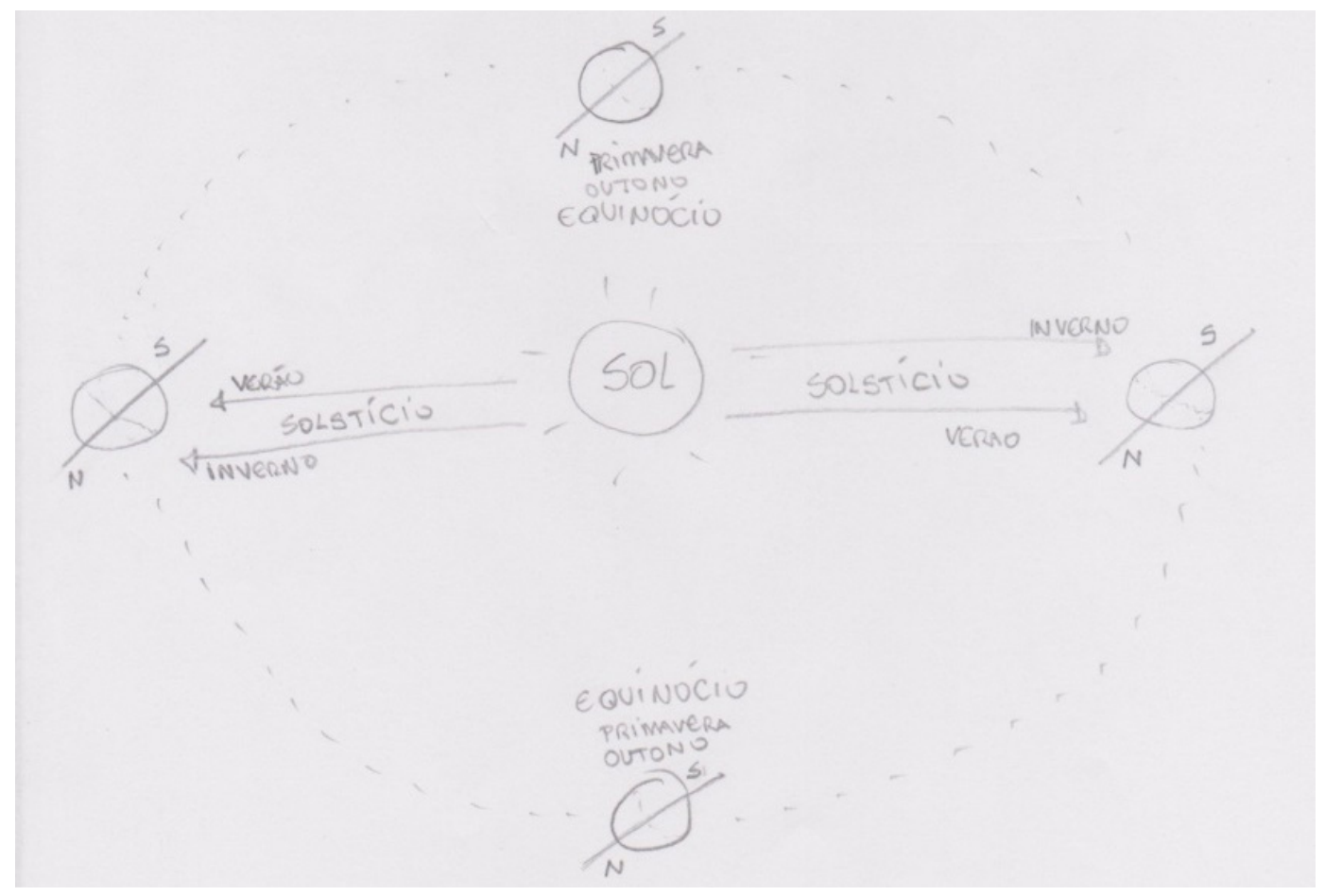

Figura 5. Representação imagética de E04 para as EA no Teste Avaliativo 


\section{Caso 2}

O segundo caso relata o estudo dos níveis significantes apresentados por um estudante em que não se acompanhou o Nível Significante Dinâmico Energético gerado pelo estudante na construção da maquete na Prática "Órbita da Terra e as Estações do Ano”. Após a realização de todas as atividades propostas, utilizando uma Diversidade Representacional no estudo das EA conforme explicitado em seções anteriores, E02 apresentou a seguinte representação textual no Teste Avaliativo:

A Terra tem uma inclinação de $23^{\circ}$ (sic), e é essa inclinação que possibilita as diferentes estações do ano, já que em determinado período um local do planeta recebe maior incidência de raios solares ficando mais iluminado e aquecido. Os polos são os que mais apresentam temperaturas abruptas, não havendo muitas diferenças, mudando mesmo que pouco a 'altura' do sol(sic) no céu (representação textual de E02 para o Teste Avaliativo).

A representação imagética gerada por esse estudante no Teste Avaliativo é ilustrado pela figura 6 .

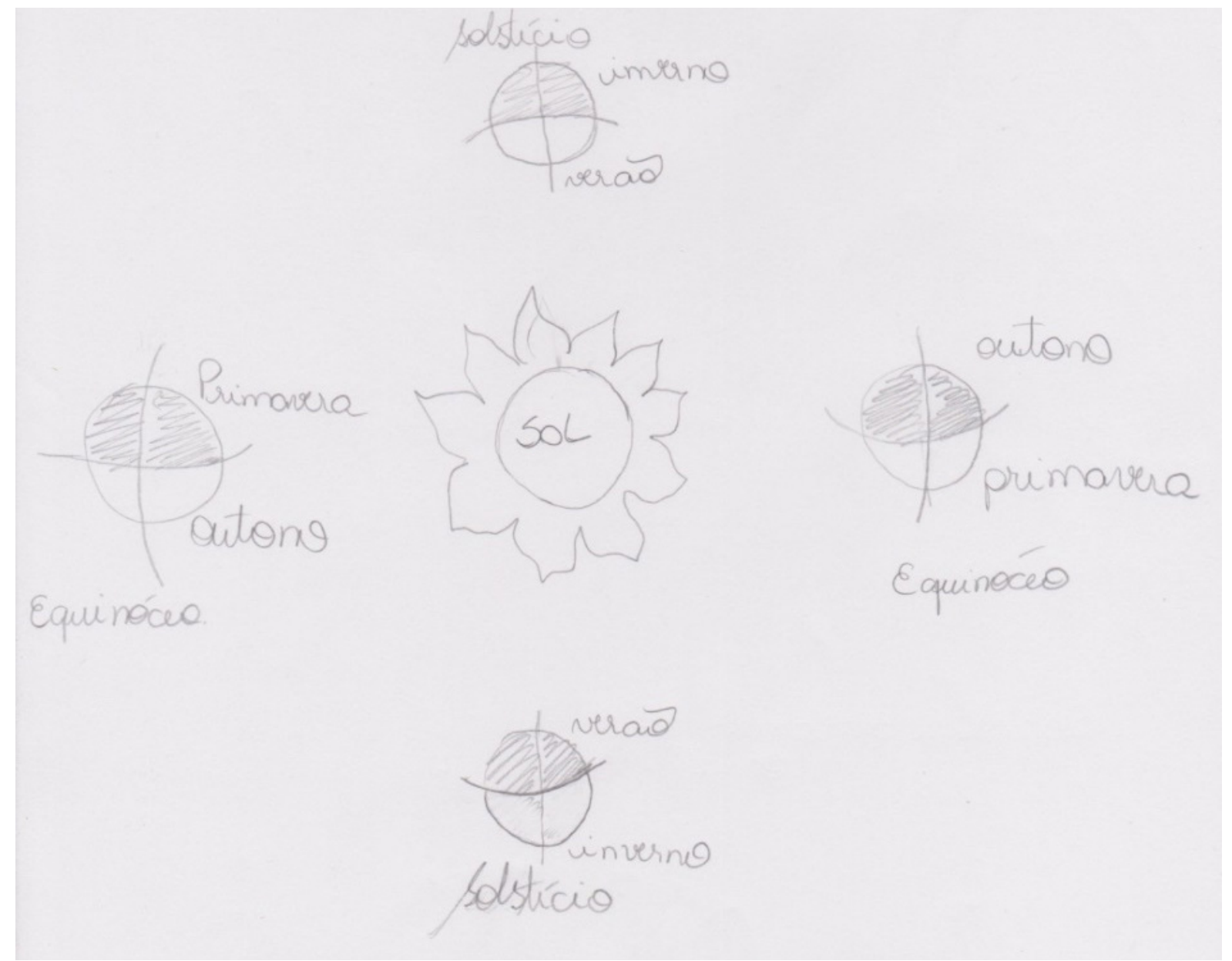

Figura 6. Representação imagética de E02 para as EA no Teste Avaliativo

O nível de significado atingido é claramente equivalente àquele estimulado por 
interferências de ensino, ultrapassando, portanto, o Nível Significante Imediato, pois E02 afirma que o motivo das EA é a inclinação de " $23^{\circ}$ (sic)" do eixo da Terra, que faz com que "em determinado período um local do planeta recebe maior incidência de raios solares ficando mais iluminado e aquecido". E02 conclui que "um local do planeta recebe maior incidência de raios solares ficando mais iluminado e aquecido" devido a "uma inclinação de $23^{\circ}$ (sic)" da Terra. A representação textual apresenta o componente [CEA2], incorreto cientificamente (pois o ângulo de inclinação é $23,5^{\circ}$ e não $23^{\circ}$ ), e [CEA3] de forma adequada. A representação imagética apresentada implica numa não harmonização com relação à representação textual, pois não ilustrou nem identificou a inclinação do eixo de rotação da Terra, apesar de tê-la mencionada na textual. Do exposto, E02 atinge predominantemente o Nível Significante Dinâmico Lógico.

\section{Caso 3}

Por sua vez, E17 construiu de forma coerente, em conjunto com seu grupo, a órbita em escala da Terra em torno do Sol durante a atividade da Prática "Órbita da Terra e as Estações do Ano”. Durante a construção da maquete, E17 auxiliou em todas as medições, que foram feitas adequadamente. Durante a discussão das posições da Terra ao longo de 1 ano com o professor, E17 e o restante do grupo identificaram corretamente as estações. O Nível Significante Dinâmico Energético de E17 foi predominantemente coerente com um possível Nível Significante Final, ao contrário do ocorrido nos dois primeiros casos relatados previamente. Para o Teste Avaliativo das EA, E17 gerou a seguinte representação textual:

O Planeta realiza o movimento de translação ao redor do Sol. Esse movimento ocorre e esse "trajeto" feito pela Terra ao redor do Sol é denominado órbita. Esse movimento, somado à leve inclinação de cerca de $23,5^{\circ}$ do planeta, em seu próprio eixo, gera as Estações do Ano, que são os períodos com maior incidência de radiação em determinados locais do globo terrestre. Tomando que, na posição 2, é verão no hemisfério Norte e inverno no Sul, uma vez que nesse ponto, a incidência da radiação solar é bem maior no HN que no HS. Já na posição 4, o hemisfério Sul recebe mais radiação do que o Norte, sendo assim verão no HS e inverno no HN. Já nas posições 1 e 3, a incidência de radiação nos dois hemisférios não é tão diferenciada, por meio disso temos primavera no HN e outono no HS na posição 1 e outono no HN e primavera no HS na posição 3. Primavera e outono que apresentam auroras boreais e austrais (representação textual de E17 para o Teste Avaliativo).

A única ausência sentida nas produções de E17 acima é a falta da representação explícita do eixo de rotação da Terra, mas percebe-se claramente que E17 entende "a leve inclinação de cerca de $23,5^{\circ}$ do planeta” pela representação imagética (Figura 7), que apresenta todos os componentes conceituais fundamentais de forma correta, com exceção do mencionado [IMEA1]. A representação verbal textual é cientificamente coerente e apropriada e menciona os três componentes conceituais fundamentais. $\mathrm{E}$ como há a coerência do Nível Significante Dinâmico Energético, podemos dizer que, 
com relação ao conceito EA, E17 atingiu predominantemente o Nível Significante Final.

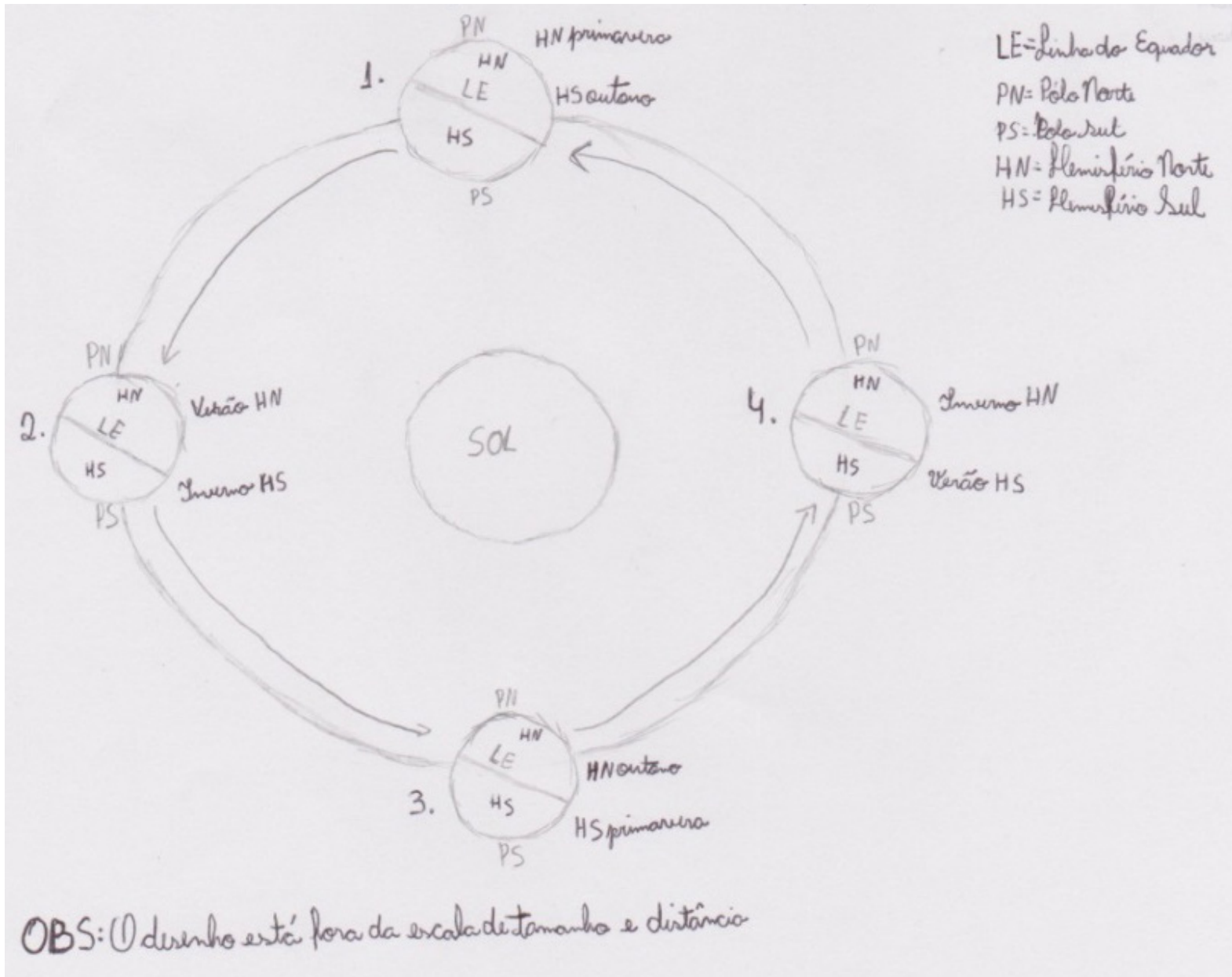

Figura 7. Representação imagética de E17 para as EA no Teste Avaliativo

\section{Considerações Finais}

Realizando-se um olhar semiótico ao significado, o presente trabalho procurou conceituá-lo segundo uma reformulação dos Interpretantes da teoria de Peirce, estabelecendo um instrumento analítico em termos dos efeitos destes produzidos na mente do aprendiz no decorrer da apropriação simbólica. O referido construto visa identificar estados de significação alcançados pelos estudantes de conteúdos científicos, motivado pela reformulação peirceana, tendo como objetivo proporcionar ao docente uma orientação teórica para qualificar o significado apropriado pelos seus aprendizes, oferecendo-o uma leitura alternativa à forma de compreender a questão do significado dado à aprendizagem.

Como os dados indicam, o uso da Diversidade Representacional contribuiu para que os estudantes atingissem significados mais profundos sobre as EA do que o Nível Significante Imediato, ultrapassando significados que eram circunscritos ao contexto dos conhecimentos prévios, senso comum, aparente, intuitivo do aprendiz. 
Em outras palavras, os alunos, através da Diversidade Representacional, apresentaram um significado elaborado acerca das EA, deixando, inclusive, de explicar o fenômeno através de "chavões" (Bisch, 1998, p. 225).

Com esse viés semiótico, olha-se para a questão dos meandros do significado por meio dos níveis significantes, o que permite ao pesquisador entender e acompanhar a construção do significado pelo aprendiz. Após o uso da metodologia de Diversidade Representacional adotada no presente estudo, com a noção de Nível Significante Dinâmico Energético, pode-se acompanhar in loco a construção do significado de conceitos científicos do estudante através dos signos expressivos emitidos nas ações ou gestos existentes nos comportamentos, atitudes, procedimentos e técnicas do aprendiz. No caso de E04, ao acompanhar o Nível Significante Dinâmico Energético do estudante na Prática "Órbita da Terra e as Estações do Ano" (A6), constatou-se que ele atribui um significado equivocado para o eixo de rotação da Terra e sua respectiva inclinação, o que compromete seu entendimento do conceito científico das Estações do Ano.

Uma implicação da utilização do instrumento analítico utilizado na pesquisa é a possibilidade de se trabalhar em termos de harmonização de interpretantes: mesmo não tendo acesso direto aos indícios do Nível Significante Dinâmico Energético gerado pelo estudante, podemos trabalhar em termos dessa concordância que pode ser analisada em termos da representação concretizada. Além disso, a ferramenta empregada se mostra útil como apoio para o docente poder tomar decisões sobre escolha de materiais didáticos e de quais seriam os próximos passos a serem seguidos. A Figura 8 mostra um possível acompanhamento pedagógico da atribuição do significado das EA de E04.

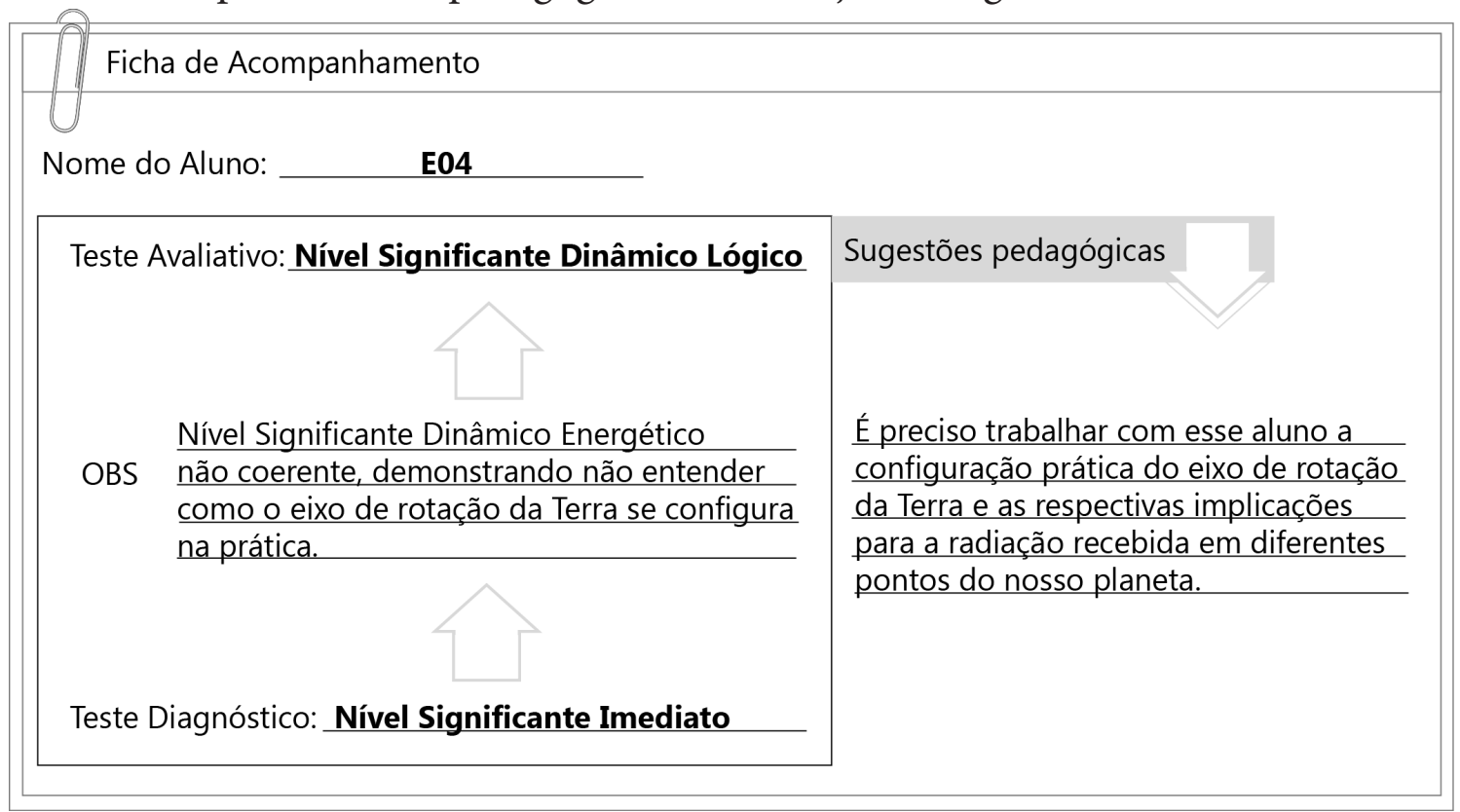

Figura 8. Possível acompanhamento pedagógico de E04

O professor pode perceber que E04 apresenta um Nível Significante Dinâmico Lógico sobre as EA, porém exibe uma não coerência entre interpretantes na construção 
da maquete. Portanto, o docente pode trabalhar essa questão com o aluno para que haja uma harmonização entre seus interpretantes, indo em direção a um possível Nível Significante Final, de forma que consiga integrar os conteúdos conceituais, procedimentais e atitudinais (Zabala, 1998) acerca do fenômeno estudado.

$\mathrm{O}$ instrumento analítico dos interpretantes se mostrou viável e aplicável para sala de aula de até 35 alunos para as aulas teóricas, em que a turma era dividida em duas turmas de até 18 alunos para as aulas práticas. A validação, fecundidade e eficácia analítica para públicos maiores, principalmente para as aulas práticas, precisa ainda ser verificado. O processo da construção sígnica em si não foi o objeto de estudo principal do presente trabalho, isto é, o Nível Significante Dinâmico Energético, caracterizado por esforços musculares dos estudantes, isto é, comportamentos, atitudes, procedimentos, técnicas originadas do processo educacional, que são traduzidos em signos emitidos através da ação, de gestos, de atos e de expressões não foi o foco principal do estudo. Dessa maneira, outra possível motivação para a continuidade desta pesquisa encontrase na sua identificação e na superação de possíveis desafios que possam aparecer nesse processo, seja executando um experimento, ou uma ação, entre outras possibilidades, pois essas ações levam o estudante a pensar e aprimorar o conceito em questão, uma vez que, de acordo com Laburú e Silva (2011b), o agir configura um ato de aprendizagem e possui função cognitiva que, em conjunto com outros modos de representação, apoia, complementa e refina a formação do pensamento científico.

\section{Agradecimentos}

Carlos Eduardo Laburú agradece ao CNPq (Bolsista CNPq/processo 302281/2015-0).

\section{Referências}

Ainsworth, S. (2008). The educational value of Multiple-representations when learning complex scientific concepts. In J. K.,Gilbert, M., Reiner, \& M., Nakhleh, Visualization: Theory and Practice in Science Education. (pp. 191-208). New York: Springer.

Ainsworth, S. (2006). DeFT: A conceptual framework for considering learning with multiple representations. Learning and Instruction, 16(3), 183-198.

Ainsworth, S. (1999). The functions of multiple representations. Computers \& Education, $33,131-152$.

Barthes, R. (1999). Mitologias. Rio de Janeiro: Bertrand Brasil S.A.

Batista, I. L. (2004). O Ensino de Teorias Físicas mediante uma estrutura HistóricoFilosófica. Ciência \& Educação, 10(3), 461-476.

Bisch, S. M. (1998). Astronomia no Ensino Fundamental: Natureza e conteúdo do conhecimento de Estudantes e Professores. (Tese de Doutorado em Ensino de Ciências). IF/USP, São Paulo. 
Buczynska-Garewicz, H. (1981). The interpretant and a system of signs. Ars Semeiotica, IV(2), 187-200.

Buyssens, E. (1967). Semiologia e Comunicação Linguística. São Paulo: Cultrix.

Cachapuz, A., De Carvalho, A. M. P., Praia, J., \& Vilches, A. (2011). A necessária renovação do ensino das ciências. 3. ed. São Paulo: Cortez.

Carvalho, A. M. P., \& Gil-Perez, D. (2001). Formação de Professores de Ciências. São Paulo: Cortez.

Clement, J. (1982). Student's preconceptions in introductory physics. American Journal of Physics, 50, 66-71.

Eco, H. (1985). O signo. Lisboa: Editorial Presença.

Epstein, I. (2002). O signo. 7. ed., São Paulo: Editora Ática.

Gardner, H. (1995). Inteligências múltiplas, a teoria na prática. Porto Alegre: Artmed.

Gee, J. P. (2008). Social Linguistics and literacies: Ideology in discourses. Routledge.

Gregersen, E. (2010). The Inner Solar System: The Sun, Mercury, Venus, Earth, and Mars. 1. ed. Britannica Educational Publishing.

Horvath, J. E. (2013). Uma proposta para o ensino de astronomia e astrofísica estelares no Ensino Médio. Revista Brasileira de Ensino de Física, 35(4), 4501.

Horvath, J. E. (2008). O ABCD da Astronomia e Astrofísica. São Paulo: Editora Livraria da Física.

Johansen, J. D. (1993). Dialogic Semiosis: an essay on signs and meaning. Bloomington \& Indianapolis: Indiana University Press.

Johansen, J. D. (1985). Prolegomena to a semiotic theory of text interpretation. Semiotica, 57(3/4), 225-288.

Laburú, C. E., \& Silva, O. H. M. D. (2011a). Multimodos e Múltiplas Representações: fundamentos e perspectivas semióticas para a aprendizagem de conceitos científicos. Investigações em Ensino de Ciências, 16(1), 7-33.

Laburú, C. E., \& Silva, O. H. M. D. (2011b). O Laboratório didático a partir da perspectiva da multimodalidade representacional. Ciência \& Educação, 17(3), 721-734.

Laburú, C. E., Zompero, A. D. F., \& Barros, M. A. (2013). Vygotsky e múltiplas representações: leituras convergentes para o ensino de ciências. Caderno Brasileiro de Ensino de Física, 30(1), 7-24.

Langhi, R. (2004). Um estudo exploratório para a inserção da Astronomia na formação de professores dos anos iniciais do Ensino Fundamental. (Dissertação de Mestrado em Educação para a Ciência). Faculdade de Ciências, UNESP, Bauru. 
Leite, C. (2002). Os professores de ciências e suas formas de pensar astronomia. (Dissertação de Mestrado em Ensino de Ciências). Universidade de São Paulo, Instituto de Física, São Paulo.

Lelliott, A., \& Rollnick, M. (2010). Big Ideas: A review of astronomy education research 1974-2008. International Jornal of Science Education, 32(13), 1771-1799.

Lima, E. (2006). A visão do professor de ciências sobre as estações do ano. (Dissertação de Mestrado em Ensino de Ciências e Educação Matemática). Universidade Estadual de Londrina, Londrina.

Ogden, C. K., \& Richards, I. A. (1989). The meaning of meaning. USA: HBJ Harcourt Brace Iovanovich.

Oliveira Filho, K. S., \& Saraiva, M. F. O. (2004). Astronomia e Astrofísica. 2. ed. São Paulo: Editora Livraria da Física.

Osborne, R. J., \& Wittrock, M. C. (1983). Learning science: a generative process. Science Education, 67(4), 489-508.

Peirce, C. S. (2005). Semiótica. São Paulo: Perspectiva.

Peirce, C. S. (1998). The Essential Peirce: Sellected Philosophical Writings/edited by the Peirce Ediction Project. Bloomington and Indianapolis: Indiana university Press (Aqui referidas como EP seguido do volume).

Peirce, C. S. (1980). Escritos Coligidos. São Paulo: Abril Cultural.

Peirce, C. S. (1931-58). Collected Papers. C. Hartshorne e P. Weiss. eds. (v.1-6) e A. W. Burks. ed. (v.7-8). Cambridge, MA: Harvard University Press. (Aqui referido como CP; os números das citações referem-se respectivamente aos volumes e aos parágrafos).

Posner, G. J., Strike, K. A., Hewson, P. W., \& Gertzog, W. A. (1982). Accommodation of a Scientific Conception: Toward a Theory of Conceptual Change. Science Education, 66(2), 211-227.

Prain, V., \& Waldrip, B. (2006). An exploratory study of teachers' and students' use of multi-modal representations os concepts in primary science. International Journal of Science Education, 28(15), 1843-1866.

Presmeg, N. (2006). Semiotics and the "connections" standard: significance of semiotics for teacher of mathematics. Educational Studies in Mathematics, 61, 163-182.

Puzzo, D. (2005). Um estudo das concepções alternativas presentes em professores de ciências de $5^{a}$ série do ensino fundamental sobre fases da Lua e eclipses. (Dissertação de Mestrado em Ensino de Ciências e Educação Matemática). Universidade Estadual de Londrina, Londrina. Santaella, L. (2005a). Matrizes da Linguagem e Pensamento. São Paulo: Iluminuras.

Santaella, L. (2005b). Semiótica Aplicada. São Paulo: Pioneira Thomson Learning. 
Santaella, L. (2004). Teoria Geral dos Signos: Como as linguagens significam as coisas. São Paulo: Pioneira Thomson Learning.

Saussure, F. D. (2006). Curso de Linguística Geral. 27. ed. São Paulo: Cultrix.

Savan, D. (1976) An introduction to C. S. Peirce's full system of semiotic. (Monograph Series of the Toronto Semiotic Circle, 1). Victoria College of the University of Toronto, Toronto.

Smith, J. P., DiSessa, A. A., \& Roschelle, J. (1993). Misconceptions reconceived: A constructivist analysis of knowledge in transition. The journal of the learning sciences, $3(2), 115-163$.

Sutopo, \& Waldrip, B. (2014). Impact of a representational approach on students' reasoning and conceptual understanding in learning mechanics. International Journal of Science and Mathematics Education, 12(4), 741-765.

Tang, K-S., \& Moje, E. B. (2010). Relating multimodal representations to the literacies of Science. Research in Science Education, 40, 81-85.

Trevisan Sanzovo, D., \& Laburú, C. E. (2016). Níveis Interpretantes apresentados por alunos de ensino superior sobre as Estações do Ano. Revista Latino-Americana de Educação em Astronomia, 22, 35-58.

Tytler, R., \& Prain, V. (2013). Representation Construction to Support Conceptual Change. In S. Vosniadou (Org.), International handbook of research on conceptual change (pp. 1009-1042). Abingdon: Taylor \& Francis.

Tytler, R., Prain, V., \& Peterson, S. (2007). Representatinal issues in students learning about evaporation. Research in Science Education, 37, 313-331.

Ullmann, S. (1964). Semântica - uma introdução à ciência do significado. 2.ed. Lisboa: Fundação Calouste Gulbenkian.

Volli, U. (2007). Manual de Semiótica. São Paulo: Edições Loyola.

Vygotsky, L. S. (2003). Pensamento e linguagem. São Paulo: Martins Fontes.

Waldrip, B., Prain, V., \& Carolan, J. (2010). Using multi-modal representations to improve learning in junior secundary science. Research in Science Education, 40, 65-80.

Wallace, C. S., Hand, B., \& Prain, V. (2004). Writing and learning in the science classroom. Holanda: Kluwer Academic Publishers: Science \& Tecnology Education Library.

Zabala, A. (1998). A prática educativa: como ensinar. Porto Alegre: Artmed. 


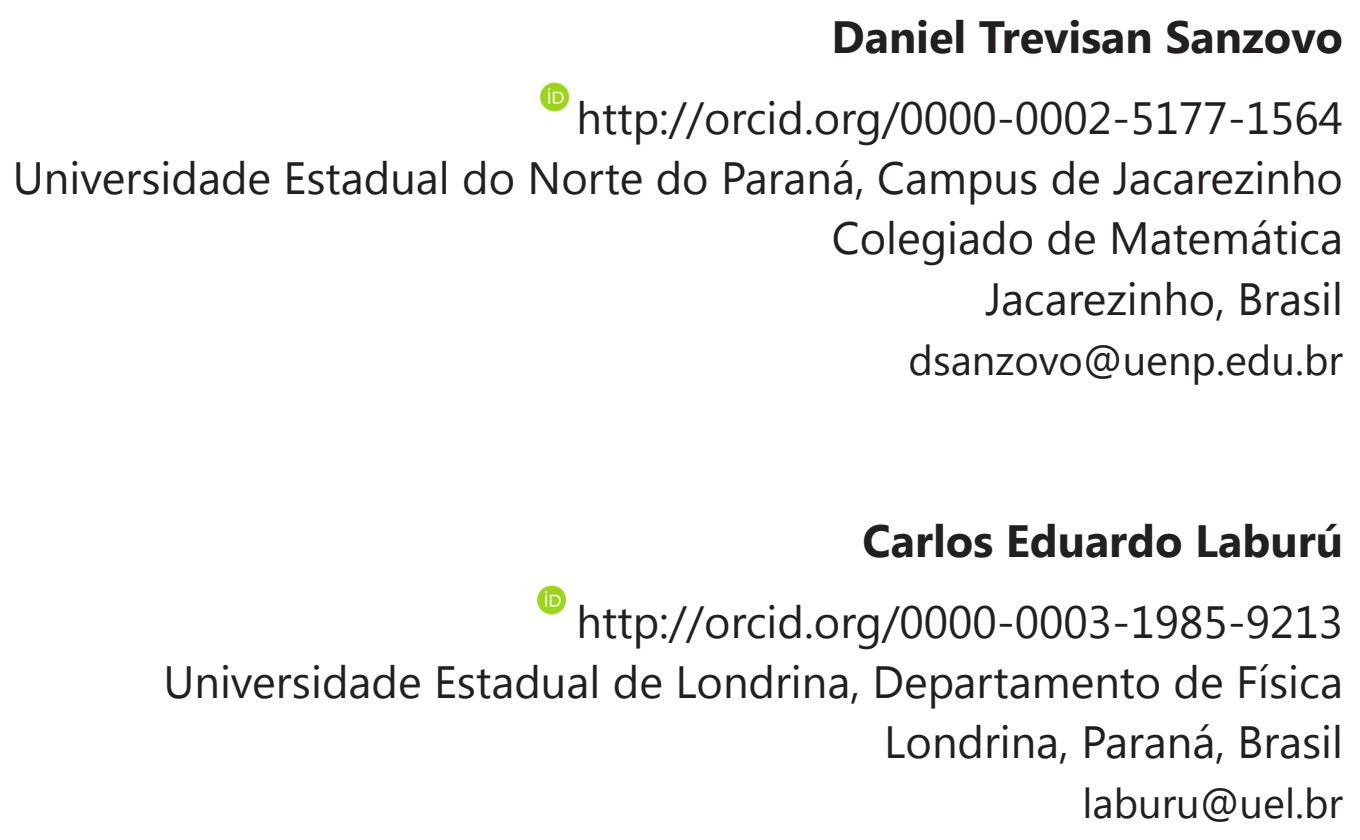

Submetido em 27 de Agosto de 2016 Aceito em 04 de Outubro de 2017 Publicado em 20 de Dezembro de 2017 